\title{
Blood lineage*
}

Guldana Salimjan

$\mathrm{T}$

he concept of blood lineage, or blood line, has been a political ideology of many monarchical regimes and aristocratic societies throughout history. The rise of nationalism in Europe in the seventeenth and eighteenth centuries paralleled the discourse about purity and the authenticity of one's blood/race. In the context of national formation, blood is a metaphor for race, ethnicity, and sexuality that enacts loyalty, belonging, and national consciousness. Blood lineage can be a malleable narrative explaining the Self and the Other, a rigid disciplinary tool reinforcing hierarchy, or a fluid signifier for social groups seeking belonging and protection. This chapter delineates the political ideology of blood lineage in China through different historical periods, with particular attention paid to its modern evolution from facilitating class struggle as a tool of social control during the Cultural Revolution, to a racialised system of securitisation that is currently occurring in the Xinjiang Uyghur Autonomous Region.

Imperial China's rulers adopted the use of blood-based ties to clarify the hereditary rights of power and property, and as a tool for social management to distinguish between royalty, civilians, and slaves. For example, the imperial Chinese punishment of collective responsibility (株连九族, literally, 'guilt by association of nine of a group/clan') and the politics of lineage, or blood relations, played an important role in moulding, disciplining, and confining people to the social roles prescribed for them. People were expected to stay in their place in society, and transgression of the boundaries of their socially or politically ordained blood lines could be met with severe punishment. In Chinese, 氏族 or 宗族 represents a group tied by blood relationships as a family or a clan, led by lineage heads (族长), with its family history and genealogy recorded as 族谱. In the late nineteenth and early twentieth centuries, 族 $(z u)$ took a 
nationalistic turn when the founding father of the Nationalist Party, Sun Yat-sen, indicated that people of the Han or Chinese race had 'common blood' and should stand together as a 'Chinese nationality' (中华民族) facing the threat of extinction under Western imperialism (Dikötter 2015: 78). After the turn of the century and the May Fourth Movement in 1919, the Republic of China was founded under the famous slogan 'Five Races under One Union' (五族共和) to unify Han Chinese and Manchus, Mongols, Tibetans, and Muslims-the major non-Han groups of China as perceived by the Nationalists. Following the Communist victory in 1949, the state's ethnologists classified 55 non-Han peoples and stressed a unified nationality comprising the Han as a majority ethnicity and non-Han as minorities (少数民族) (Bulag 2019). Official discourse aside, popular memories and heroic narratives centred on blood lineage also thrived. For example, the Han nationalist imagination proposed a linear history of ancient China in which an immutable Han racial identity continually existed by identifying themselves as descendants of the mythological Yan and Huang emperors (炎黄子孙).

\section{The 1950s: Building a new nation}

After the Chinese Communist Party (CCP) took control of mainland China in the 1950s, the discourse on blood lineage temporarily shifted away from national or racial concerns to struggles over class identity, but the notion of heritability remained. Under Mao Zedong's guidelines for class struggle, individuals were labelled with a class identity according to birth or family relationships. Despite contradicting the socialist goal of eradicating imperial practices, reckoning by blood was effectively institutionalised by those in power through the practice of class struggle, as it justified the monopoly over social and political resources of the privileged while disenfranchising and suppressing vulnerable groups, such as those who did not comply with or challenged such arrangements.

During the early 1950s, Mao's land reform and class-motivated purge of landlords virtually removed the authority of reproductive ties between powerful lineage groups within rural communities. Throughout China, previously ruling classes saw massive socialist transformations: land was confiscated from landlords and distributed to landless and poor peasants and private merchants and capitalist industries gradually became stateowned. Blood became a form by which to assess one's revolutionary subjectivity through family background (出身) or class labels (阶级成分). 
The 'good ones' were reproduced and circulated as revolutionary agents within the national body, and the 'bad ones' were identified as reactionary or bad-blooded and outcast. A person's class or family background not only haunted his or her own life, but also the lives of their spouse, children, and other relatives. In Michael Dutton's (2004: 168) words, the class-related political problems recorded on personal dossiers can 'spread like a virus' to the files of their family members, marking them also as untrustworthy, and in this way class becomes a 'blood-borne disease'. The unfavourable classes were labelled the 'Four Black Categories' (黑四 类): landlords, rich farmers, counterrevolutionaries, and bad-influencers. After the Anti-Rightist Campaign in 1957, 'rightists' were added to the list, making Five Black Categories.

In non-Han peripheral regions such as Inner Mongolia, Tibet, and Muslim-populated Xinjiang, local political groupings, religious authorities, and hereditary leaderships were also dismantled during the socialist reform. Following Western intellectual traditions of social evolutionism, party cadres and ethnologists depicted the Inner Asian pastoral aristocracy's houses of power as a primitive tribal kinship society (in Chinese, 部落 or 氏族), but also denounced them as 'capitalist' since the rich herders were accused of accumulating capital in the form of livestock and thereby reproducing oppressive class relations in pastoral production. State power materialised in omnipresent institutions in these native communities, such as the 'pastoral office' and the 'pastoral production cooperative', with Han administrators promoting the Communist Party's work and policies in non-Han regions. The discourse on blood lineage in these regions was used to depict pastoral people simultaneously as backwards or stuck in time and having advanced the pastoral economy to a stage of economic modernity in which capitalists could exist, and therefore worthy of persecution.

When necessary, the Party-State was tactical and flexible in instrumentalising lineage as a political tool among the pastoralists; at other times, the state obliterated those lineages when they threatened perceived national interests. As the denunciation of local authorities continued, CCP cadres also reflected on their lack of understanding of pastoral social structure, especially the great social power and influence of lineage heads. They realised pastoral lineage heads were crucial targets for cooptation after careful indoctrination. This method effectively assured the mobilisation of powerful local leaders to assist in the dissemination of party policy, propaganda, and new modes of socialist animal husbandry. For example, 
in northern Xinjiang, Han ethnologists surveyed the Chinggisid lineage of the Kazakh noble Tore clans in detail and evaluated their productivity, eventually restructuring them into major production brigades as a form of state 'socialist primitive accumulation.' ${ }^{1}$ On the eve of Mao's Great Leap Forward (1958-62), interethnic relations became tense due to the expanding people's commune system and a huge influx of Han settlers into traditionally non-Han regions. As the overwhelming scale of socialist transformation in ethnic minority borderlands led to resistance in these regions at the end of the 1950s, the CCP simply denounced the resistance as 'local nationalism' (地方民族主义)-a 'counterrevolutionary' crime to be purged. The ever-shifting target of blood lineage in Xinjiang exemplifies the malleable nature of blood lineage in twentieth-century Chinese politics.

\section{The politics of communist lineage in the Cultural Revolution}

During the Cultural Revolution, the idea of blood lineage (血统) was revamped and gained a sinister level of national popularity. At the same time, Mao's notion of the class line (阶级路线) opened a path away from one's background based on one's revolutionary devotedness and political behaviour. Those from good family backgrounds-called the 'Five Red Categories' (红五类): poor and lower-middle peasants, workers, revolutionary soldiers, revolutionary cadres, and revolutionary martyrsdeclared they were the legitimate successors of the socialist revolution and 'red by birth' (自来红). The Five Black Categories were expanded to nine, with new additions being capitalists, capitalist roaders, traitors, and spies. In 1966, a couplet began to circulate after appearing at the Beijing Aeronautical Engineering Institute. It read: 'A hero's son is a real man; a reactionary's son is a rotten egg' (老子英雄儿好汉; 老子反动儿混蛋).

At first, high officials in the CCP criticised this blood lineage idea and stressed that one's political behaviour or expression (政治表现) was also important. However, in practice, the hierarchical categorisation and political naming prompted discriminatory policies aimed at

\footnotetext{
I There are multiple terms to describe genealogical and political groupings in Kazakh society (for example ulus, ru, juz) and they are inconsistently translated in English and Chinese sources - a result of early British anthropology's ideological perceptions of 'tribes' and 'clans' in Africa. The Chinese sources for this material used 部落, which in modern Chinese can be loosely translated as clan or tribe. However, as Morton Fried (1966) and Daniel Biebuyck (1966) argue, 'tribe' simplifies the innate complexity of a group's terms for social organisation.
} 
innocent individuals with bad family backgrounds or class labels. It stamped indelible institutional marks on the countless bodies of the Nine Black Categories (黑九类), whose children were euphemistically referred to as 'teachable offspring' (可教育好的子女). In fact, they were deprived of any rights to political or social participation. Under this regime, they had to earn leniency or better treatment through good 'political behaviour' such as making a clean break with their reactionary parents and family backgrounds. Some cases resembled the imperial penal style of 'implicating associates' when the class labels of up to three generations were scrutinised. The 'teachable offspring' were often excluded from opportunities such as joining the army or acceptance into schools. They were subjected to unequal pay and reform through labour, and their unbearable humiliation and torture led to numerous unnatural deaths.

Yu Luoke, a young worker from Beijing, made a powerful counterargument to the Red Guards' principle of blood lineage. Having suffered from the negative impact of his father's 'rightist' background, in 1967, Yu published the essay 'On Family Background' (出身论). Quoting Marxist and Maoist theories, Yu pointed out that one's family background should not be equated with one's political identity and revolutionary consciousness. Moreover, the principle of blood lineage could not justify violence against people without a good family background; in this sense, the Five Red Categories were the oppressors. Yu's argument shook the foundation of the party's revolutionary legitimacy by rendering illegible the categories of class struggle. Without a clearly identified set of heroes and villains, the machinery of class struggle would break down. The party became desperate for a consolidation of self-identity, ideological control, and epistemological certainty. The principle of blood lineage came in handy because it isolated people into different categories and stratifications and screened the political disloyalties of those who could challenge the CCP's status quo. As a result, top officials chose not to follow through with their criticism of blood lineage but instead exploited it as a social governing mechanism. Yu's calls for equal human rights as intrinsic to socialism eventually touched a sensitive nerve with the party authorities. In 1970, he was executed for the crime of 'organising counterrevolutionary groups'.

For non-Han pastoral societies during the Cultural Revolution, the system of class labelling established new hierarchical political categories that replaced previous ones and significantly frayed the fabric of society and individual families. Mongol landlords who leased land to Han peasants were denounced and disenfranchised in the name of 
class struggle (Bulag 2000). In Tibet, class struggle heightened internal divisions and led to tens of thousands being killed in 'struggle sessions' or sent to reform through labour (Woeser 2020). In northern Xinjiang, nomadic pastoral nobility had formerly protected their lineages by not allowing their women to marry men of lower status, at least in principle. This was reversed after CCP cadres conducted struggle sessions denouncing landlords and aristocrats, and they went as far as forcing marriage across class differences.

\section{Ghosts of blood lineage today}

After the Cultural Revolution, the CCP abandoned the principle of blood lineage, but the generation who benefited from it had already attained high positions in powerful national-level political and economic organs. Many have gone on to generate profits for their entire family from corrupt practices and abuses of power, capturing the prosperity produced through the privatisation of public goods during the reform era. Numerous cases have been exposed illustrating the ways in which these second-generation elites and bureaucrats enjoy above-the-law lifestyles and hold billions of dollars in offshore accounts. It has been an unspoken rule in China that the offspring of elite groups inherit their father's privilege; they have been given nicknames such as 'officialings' (官二代), 'red second generation' (红二代), and 'princelings' (太子党).

The ghosts of blood lineage continue to haunt non-Han regions in the twenty-first century as a new era of state racism dawns. While pseudo-traditional symbols of 'Chinese culture' such as the Han costume movement, Confucian memorial ceremonies, and virtue training schools for women mushroomed in mainland China, Tibet and Xinjiang have been increasingly subjected to state-led exploitative development projects at the expense of native peoples and lands. Temporary pluralism and multiculturalism in the reform era have given way to Han-centred empire-building aimed at rooting out ethnic, religious, and cultural differences as social deviancy and disease. This is simultaneously shaped by Western discourses fostered by the US-led War on Terror and global Islamophobia (Roberts 2020). China's use of this discourse has fostered its own industrial complex of 'terror capitalism' (Byler 2021): hightech Orwellian social control targeted mainly at Turkic Muslim and Tibetan populations. So far, hundreds of thousands of Uyghurs, Kazakhs, Kyrgyz, and other ethnic minorities have been detained indefinitely in 
'concentrated reeducation and transformation centres' (集中教育转化中 心), without indictment or fair trial. Echoing the West's 'War on Terror' and racialisation of Muslims, Chinese authorities have also framed Uyghurs as 'bad Muslims' (see Brophy's Chapter 4 in this volume) who need to be reengineered through forced political indoctrination and labour. This view of Uyghurs as a dehumanised, racialised Other is clear in a speech by a Han official in Xinjiang:

You can't uproot all the weeds hidden among the crops in the field one by one-you need to spray chemicals to kill them all. Re-educating these people is like spraying chemicals on the crops. That is why it is a general re-education, not limited to a few people. (Hoshur 2018)

The CCP initially shifted away from the racial/nationalist discourse of mid-twentieth-century political movements, but it has rekindled those flames by explicitly combining the discourse on blood lineage with ethnicity in places like Xinjiang. Blood as a metaphor of social differentiation and guilt by association are implied in leaked official party documents from Xinjiang, in which a point system is utilised to criminalise family members, both in and outside the camps. In this document, officials are instructed to tell students whose parents have disappeared into the detention camps:

Family members, including you, must abide by the state's laws and rules, and not believe or spread rumors ... Only then can you add points for your family member, and after a period of assessment they can leave the school if they meet course completion standards. (Ramzy and Buckley 2019)

This process of hyper-criminalisation is unprecedentedly aided by cutting-edge technologies in biodata collection and surveillance networks. Since the end of 2016, a military technology used for national defence has been applied in Xinjiang, called the Integrated Joint Operation Platform (一体化联合作战平台). This security system instantly gathers data on individuals from multiple sources such as banks, medical providers, and travel histories to analyse, make predictions, and generate lists of suspects. Human Rights Watch (HRW 2018) reports that, under this system, Uyghurs who have been arrested or are deemed 'unsafe' are 
differentiated from others and their personal dossiers are tagged in a different colour. Xinjiang residents also have been required to fill out a Population Data Collection Form (see Figure 3.1) and report whether they are Uyghur, whether they are 'persons of interest' (beyond a scale of one to five, there exists an extra 特, or special security level), whether they are relatives of a detainee or of someone being subjected to crackdown and punishment, whether they are tagged by the Integrated Platform, and whether they have contacts abroad and how they are related (Chin and Bürge 2017). They also must submit detailed information including their religious habits, whether they have a passport and have travelled abroad, and so on. Moreover, Chinese AI companies such as SenseTime, Hikvision, and CloudWalk have developed facial recognition cameras and DNA tracking to automatically detect Uyghurs by their phenotypes (Mozur 2019). Blood samples and images of irises were also unethically collected from Uyghurs and other targeted groups to aid the development of such DNA phenotyping technologies (Wee and Mozur 2019). The Party-State's population-control measures have metamorphosed into a highly organised blood lineage classification system with layers of class, political, racial, and geographical inputs. Based on the collected data, officials then categorise people in terms of reliability into three groups: safe, average, and unsafe. The collected family information enables the authorities to track down and terrorise people even when they are outside China.

While Uyghur and Kazakh masculinity were ostensibly tamed through carceral governance in Xinjiang, women's bodies became the next frontier for the state to deploy its settler politics in sexuality and reproduction. In its initial nation-making process in the early 1950s, to solve the gender ratio imbalance, the paramilitary settlers of the Xinjiang Production and Construction Corps recruited thousands of female students, soldiers, and prostitutes from Hunan and Shandong provinces to populate the settlements. Following Mao's dictate about 'anti-Han chauvinism' and maintaining border stability, interethnic marriage between Han settlers and local Muslims was strictly prohibited. Though the Han population has continued to increase in the past decades, low rates of Han-minority marriages are seen as an indication of ethnic tension in Xinjiang, while Uyghurs view the avoidance of such interethnic marriages as a type of resistance (Smith Finley 2013). In 2014, the state changed its policy and started to offer incentives to encourage interethnic marriage (Wong 2014). From 2015, propaganda depicting secularised mass weddings as 'new fashion weddings' to delegitimise Islamic nikah ceremonies and other 
indigenous marriage customs as a form of 'counterterrorism' work has become prevalent.

From the debate about blood lineage and class labelling to today's detention of Muslim minorities in Xinjiang, blood is a powerful symbol the Party-State uses to envision and sometimes cleanse its political and national body. As the CCP no longer needs to mobilise ethnic minorities as a united front, it has embarked on a mission to establish itself as an ever-expanding Chinese nation focused on Han interests. From imperial China to revolutionary movements and the War on Terror, the discourse on blood lineages remains a flexible political tool for the state. As the marriage of biotechnological surveillance techniques with Mao-era political ideas about blood lineage in Xinjiang suggests, the principle of blood lineage is still an important concept for understanding Chinese politics and society, and will remain so for the foreseeable future. 
人口信息采集表

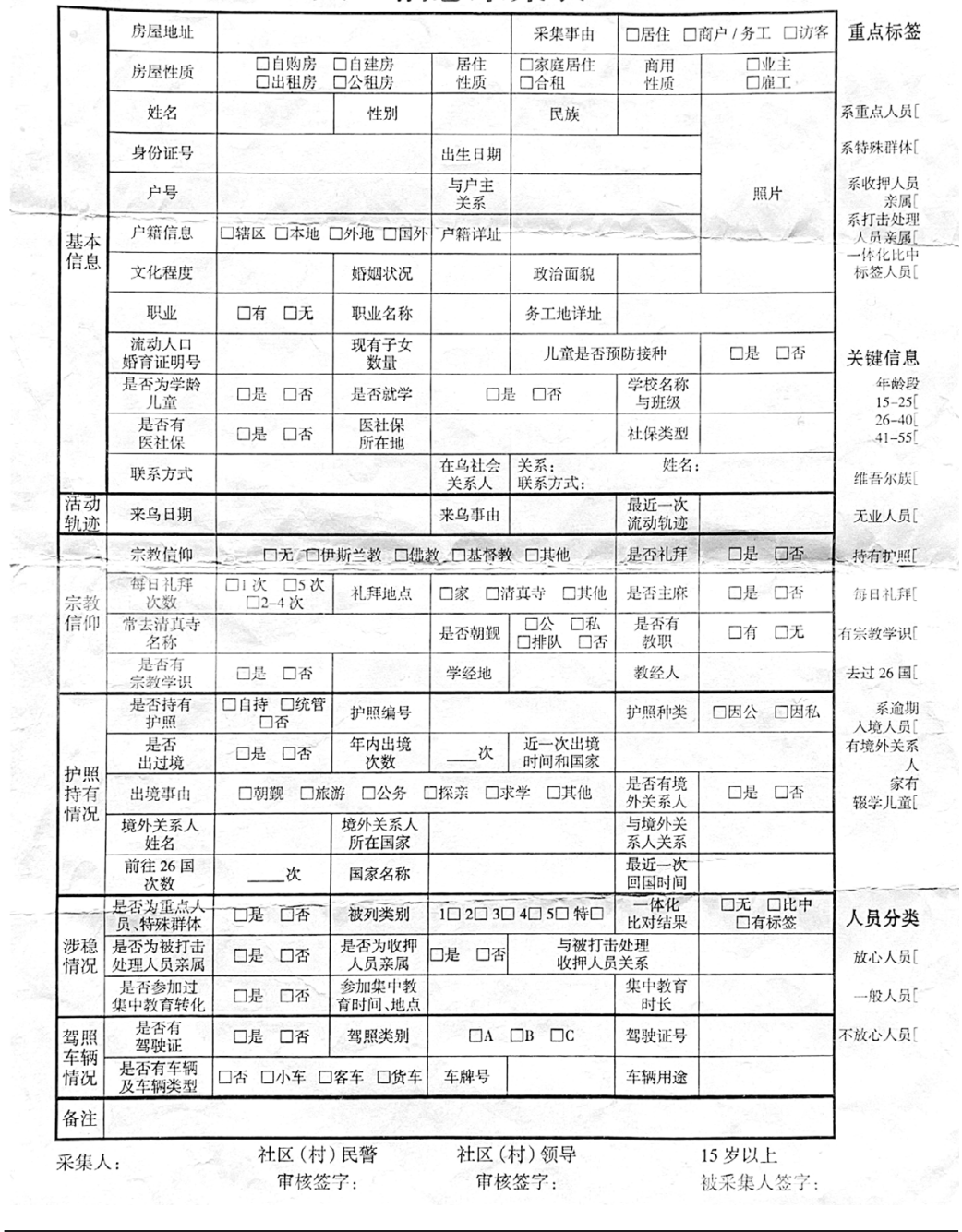

Figure 3. I The Population Data Collection Form that Xinjiang residents are required to fill out. Form provided by Tahir Hamut. 
This text is taken from Xinjiang Year Zero, edited by Darren Byler, Ivan Franceschini and Nicholas Loubere, published 2022, The Australian National University, Canberra, Australia.

doi.org/10.22459/XYZ.2021.03 